\title{
Sustainable Development as a Macro-Regional Goal
}

\author{
Donatella Porrini* and Fabrizio Striani
}

\author{
Università del Salento, Lecce, Italy
}

\begin{abstract}
The idea of sustainable development emerged both from science and the environmental movement in the 70 s and $80 \mathrm{~s}$ of last century. Since then a lot was done in the field, sometimes without even naming it "sustainable development", but a lot still remains to be done. In this paper we start from the consideration that sustainable development requires that we see our world as a system that connects space and any discussion today must first consider the enormous impacts that modern globalization trends are playing in shaping the economic geography of places, such as macro-regions. In the future, macro-regional development could be the most important platform for enhancing sustainability. The regional dimension is suitable for redefining the meaning of sustainable social, economic and environmental systems in a way which is practical and very close to the people and to the operative public decisions (Alkan Olsson et al. 2004). This paper is divided in different sections: the first is about the regional sustainable development concept and place-based approach; the second is about Local Agenda 21; the third about regional integration and developmental regionalism; the fourth is about regional sustainable development in practise and the European macro-regions; at the end some conclusive remarks concerns the macro-regional future strategies addressing sustainable development.
\end{abstract}

Keywords: Sustainability, regional integration, territorial development.

\section{INTRODUCTION}

The idea of sustainable development emerged both from science and the environmental movement in the 70 s and 80 s of last century. Therefore, sustainable development means different things but the most frequently quoted definition is undoubtedly "development that meets the needs of the present without compromising the ability of future generations to meet their own needs"1.

There are, in general, three essential aspects of sustainable development (Harris, 2003):

- Economic: An economically sustainable system must be able to produce goods and services on a continuing basis, to maintain manageable levels of government and external debt;

- Environmental: An environmentally sustainable system must maintain a stable resource base, avoiding over-exploitation of renewable resource systems or environmental sink functions, and depleting non-renewable resources; and

- Social: A socially sustainable system must achieve fairness in distribution and opportunity,

*Address of correspondence to this author at the Dipartimento di Scienze dell'Economia, Department of Management, Economics, Mathematics and Statistics, Via per Monteroni, 73100 Lecce, Italy; Tel: +39.0832.298.776;

Fax: +39.0832.298752; E-mail: donatella.porrini@unisalento.it

${ }^{1}$ World Commission on Environment and Development's (the Brundtland Commission) report Our Common Future, Oxford: Oxford University Press, 1987. adequate provision of social services such as health care and education, gender equity, and political accountability and participation.

Sustainable development, then, is a complex concept, dealing with multiple disciplines and different spatial scales. It indicates a societal process whereby the development goal is subject to changes throughout the process that can deal with multiple actors and different geographical entities.

There are several key features of the modern era of globalization as it relates to economic geography. First, most of the global economy is experiencing a period of slow international convergence, whereby poorer countries are catching up with richer countries, both due to their internal structural transformations and also as firms in richer countries take advantage of the new trade and investment possibilities available in the lower income countries (Ascani, Crescenzi and lammarino 2012).

However, the picture is complex. The majority of Africa has been excluded from the convergence process. Second, global trade has shifted eastward due to the rise of the Asian economies, and most notably China and India. Third, the three super-regional areas of integration (in the Figure 1), namely, the EU, NAFTA, and South and East Asia, have increased their share of almost every indicator of global economic activity, implying that global activity is increasingly concentrating in these three super-regional areas of integration (Barca et al. 2012). 


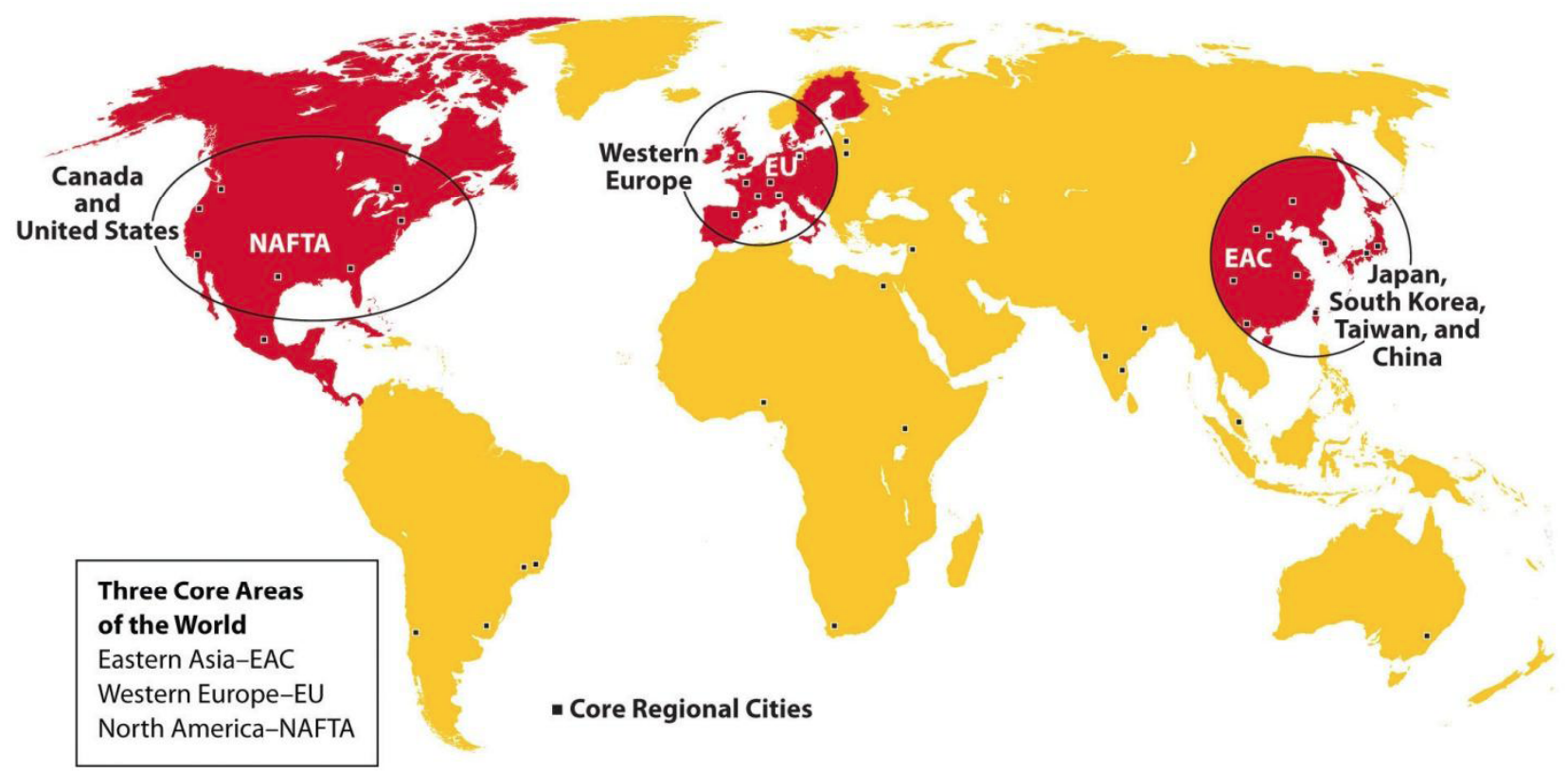

Figure 1: Super-Regional Global Areas.

The extent to which many regional integration initiatives actually promote sustainable development is varied and debates on the merits of regional integration in the promotion of sustainable development are ongoing with opposite results.

In this paper we start from the consideration that sustainable development requires that we see our world as a system that connects space and any discussion today must first consider the enormous impacts that modern globalization trends are playing in shaping the economic geography of places, such as macro-regions.

In the future, macro-regional development could be the most important platform for enhancing sustainability. The regional dimension is suitable for redefining the meaning of sustainable social, economic and environmental systems in a way which is practical and very close to the people and to the operative public decisions (Alkan Olsson et al., 2004).

This paper is divided in different sections: the following is regional sustainable development and place-based approach; the third is about the regional sustainable development concept and Local Agenda 21; the fourth is about regional integration and developmental regionalism; the fifth is about regional sustainable development in practise and the European macro-regions; at the end some conclusive remarks concerns the macro-regional future strategies addressing sustainable development.

\section{REGIONAL SUSTAINABLE DEVELOPMENT AND PLACE-BASED APPROACH}

The place-based approach (PBA), in essence, promotes dialogue between institutions and actors pursuing development at different geographical scales. Such dialogue allows governments to take into consideration local specificities and assets, while designing and implementing various development policies and simultaneously avoiding domination of the local or regional self-interests prevailing in highly decentralized policymaking models. The assumption is that the place-based approach improves performance of development policies by stimulating endogenous development potentials, catering policy to local circumstances, and properly outlining the role of territorially bound assets, such as settlement structure and accessibility infrastructure, in pursuing development (Barca 2009).

The place-based approach can most simply be defined as stakeholders engaging in a collaborative process to address issues contemporaneously, as they come up within a geographic space.

The PBA, then, offers two types of benefits: on one hand, it covers important elements and mechanisms constituting smart, inclusive and sustainable growth; on the other hand, it increases policy performance.

In fact, the key message out of this approach is the following: "Development - both in its economic and social dimensions - can be promoted in (almost) any 
place by a combination of tailor-made institutions and integrated public investments designed through the interaction of agents endogenous and exogenous to that place" (Zaucha and Świątek 2013:8).

In formal terms the place-based approach implies:

- a long-term development strategy whose objective is to reduce persistent inefficiency (underutilization of the full potential) and inequality (share of people below a given standard of well-being and/or extent of interpersonal disparities) in specific places;

- the production of bundles of integrated, placetailored public goods and services, designed and implemented by eliciting and aggregating local preferences and knowledge through participatory political institutions, and by establishing linkages with other places (Barca 2009);

- the promotion from outside of the place by a system of multilevel governance where grants subject to conditionalities on both objectives and institutions are transferred from higher to lower levels of government.

Barca (2012), following this approach, affirms that development requires relations between local decision makers (local developmental agents) and exogenous forces (e.g. national government) in order to tailor policy interventions to the specificity of different places (including its territorial capital) and in the same time avoid rent seeking behavior (domination of local selfinterest). Such dialogue is also essential for activation of endogenous potential end ensure ownership of policy interventions. The dialogue should reveal how development of a given "place" is important for development of the entire country and vice versa how national development (e.g. of the transport infrastructure) will influence well-being of the given place. Therefore knowledge on a given place and the broader developmental context is necessary.

The place-based argument suggests that development strategies should thus focus on mechanisms which build on local capabilities and promote innovative ideas through the interaction of local and general knowledge and of endogenous and exogenous actors in the design and delivery of public policies (Barca et al. 2012), creating multi-sectorial policy framework involving the provision of different bundles of public goods to different localities.

\section{THE LOCAL AGENDA 21 AND RECENT DEVELOPMENTS}

After the 1992 United Nations Conference on Environment and Development (UNCED) in Rio de Janeiro the discussion of how science and technology could contribute more effectively to sustainable development intensified. After the World Summit on Sustainable Development (WSSD) in Johannesburg in 2002 the strongest message for science was that the research community needed to complement its traditional role of identifying problems of sustainable development with a greater willingness to join with other communities to work on practical solutions to these problems.

The first action plan for sustainable development was Agenda 21 defined in 1992 Rio Conference as an action program that has to be implemented by governments, UN agencies, local and regional administrators, organizations in the community and the general public. Governments are required to promote the dialogue among these players, but local government, too, closest as it is to the public at large, has a responsibility and has been allocated a major role in providing information, education and mobilizing the general public to achieve sustainable development.

One of the objectives of Agenda 21 is that every local government should draw up its own Local Agenda 21 in close consultation with its citizens, on the base of the assumption that "most of the problems and solutions which Agenda 21 addresses have their origin in local activities", the document is directed primarily to local governments, as "representing the level of government closest to the people, they play a vital role in raising awareness, mobilize and respond to citizenship for promoting sustainable development" (Delle Cave 2015).

The document sets out the basic principles of the initiatives, identifying a central element in the definition of specific methods of consultation, information sharing, building consensus on which should the dialogue between local government, citizenship, economic sectors and civil society on issues sustainable development should be set.

From the Rio Conference, the experiences of Local Agenda 21 have multiplied, becoming one of the main means of achieving the goals set in 1992 as a part of a more general process of multi-level integration of environmental policies pursued at regional, national and European level. 
The Sixth Environmental Action Plan of the European Community 2002-2012, assigned a central role to the consultation, participation, sharing of responsibilities between different levels of government, that, in the light of the principle of subsidiarity, are crucial for the continuity of actions. In this respect, the preparation of sustainability strategies at all levels is promoted, for the implementation of these objectives in relation to their specificity, adapting to these contents and priorities in collaboration and partnership with local authorities and all parties involved" (Delle Cave 2015).

Characterized by open processes and an highly territorial dimension, the development of Local Agenda 21 experiences was divided into modalities and trends which change according to the contexts, to the environmental needs addressed, the type of actors involved, and other factors characterizing the individual local variations, enriching the landscape of practices and experiences with highly differentiated trials around some common denominators:

- The multi-sectorial planning process, coordinated by a body composed of local stakeholders, whose equal participation in the process is configured primarily as a mechanism of mobilization of cultural, human, planning, ideals, relational resources;

- Consultation with partners that are part of civil society such as local associations, NGOs, entrepreneurs, government agencies, professional associations, trade unions, expressions of the research world, religious congregations, which aim to share goals and identify proposals for action;

- Common assessment of the social, environmental and economic premises;

- The horizontal or cross-disciplinary approach, involving the integration process within the whole complex of activities of local institutions;

- The common definition of objectives through processes of negotiation between the main stakeholders;

- $\quad$ The global and long-term perspective with which the issues of sustainability of local processes are tackled;

The use of monitoring and evaluation processes, oriented to track progress and maintain a high level of mutual accountability among the participants.

From the clear centrality of the process as a factor determining the Local Agenda 21 initiatives, descends the importance of the methodological framework applied. Importance that, on one hand reflects an awareness of an attention to the system of the process, on the other does not translate into a rigid methodological definition, as in a consolidation of landmarks around some basic principles developed at international level, which is adding modulations outlined at the local level and scattered through the relations between local entities committed to sustainability issues.

The Aalborg Charter as well as the European Union's Sustainable Cities and Towns Campaign and the 6th European Environmental Action Programme refers to the use of indicators able to capture the different dimensions of sustainability and adapt to the specificities of local contexts, to consider as means of orientation both during the preparation of strategies, and in the verification of the results. At the national level, a point of reference is indicated in the Guide to Local Agenda 21 published by the National Agency for Environmental Protection referring to the $10+1$ European Common Indicators (ECI), which, thanks to the recognition at European level, allows to compare the results with those of all the local authorities in Europe who adopt them.

The ECls have been developed within a joint project with the participation of several organizations and local authorities with the aim of encouraging local authorities in Europe to use them as the baseline indicators complementary to national or local ones. The parameters tested are indicative of the quality of the environment (emissions, air quality, noise pollution), the quality of environmental policies and behaviours (mobility, land use, sustainable consumption), the perception of the quality of life, to which is added the eleventh indicator that refers to the ecological footprint of the population that insists on the territory.

The process of developing a new set of Sustainable Development (SD) goals was initiated by the UN Conference on SD in Rio de Janeiro in 2012, the socalled Rio+20. The outcome document, titled The Future We Want, established a common vision for the future by reaffirming a global commitment to the principles of SD. It reaffirmed the commitment to advance integration, implementation and coherence, to 
assess progress to date and to address new and emerging challenges as well as to engage major groups and stakeholders in promoting SD.

After that, a total of 17 universal goals was adopted by the UN General Assembly on September 25, 2015 as part of a new global 2030 Agenda, which will be in effect from 1 January 2016 through 31 December $2030^{2}$.

Implementing the SDGs has significant challenges. Gaps in the implementation of the SD agenda exist at all governance levels, including national, regional and international levels (United Nation 2015). These gaps come from a number of sources, such as the notion that SD has a vague character, that many stakeholders see it differently, and that the SD agenda is driven by markedly differently ambitions.

There may also exist differences across governance levels in terms of implementing the global SD agenda. The SD goals underline the enhanced role of multistakeholder partnerships as a complement to global the institutional framework and inter-governmental arrangements for SD. Multi-stakeholder partnerships for SD should be viewed as a mobilizer, which shares knowledge, expertise, technologies and financial resources to support the achievement of SDGs in all countries. Institutional frameworks and intergovernmental arrangements for SD, and the means of implementation via e.g. financial resources,

\footnotetext{
${ }^{2}$ The UN Sustainable Development Goals:

Goal 1. End poverty in all its forms everywhere

Goal 2. End hunger, achieve food security and improved nutrition and promote sustainable agriculture

Goal 3. Ensure healthy lives and promote well-being for all at all ages

Goal 4. Ensure inclusive and equitable quality education and promote lifelong learning opportunities for all

Goal 5. Achieve gender equality and empower all women and girls

Goal 6. Ensure availability and sustainable management of water and sanitation for all

Goal 7. Ensure access to affordable, reliable, sustainable and modern energy for all

Goal 8. Promote sustained, inclusive and sustainable economic growth, full and productive employment and decent

work for all

Goal 9. Build resilient infrastructure, promote inclusive and sustainable industrialization and foster innovation

Goal 10. Reduce inequality within and among countries

Goal 11. Make cities and human settlements inclusive, safe, resilient and sustainable

Goal 12. Ensure sustainable consumption and production patterns

Goal 13. Take urgent action to combat climate change and its impacts

Goal 14. Conserve and sustainably use the oceans, seas and marine resources for sustainable development

Goal 15. Protect, restore and promote sustainable use of terrestrial ecosystems, sustainably manage forests, combat

desertification, and halt and reverse land degradation and halt biodiversity loss

Goal 16. Promote peaceful and inclusive societies for sustainable development, provide access to justice for all and

build effective, accountable and inclusive institutions at all levels

Goal 17. Strengthen the means of implementation and revitalize the global partnership for sustainable development
}

technology transfer and capacity building need to be strengthened.

The new 2030 Agenda needs to not be limited to action on one level of governance, but rather by activities across levels to be able to deal with multidimensional issues such as energy, water management and food security. To address development in this integrated way it needs to be aligned with current governance frameworks. These have undergone a profound shift during the last decades, especially by the increased importance of multi-layered governance levels typical for the European Union (EU). Different levels of governance are important since the both facilitate and drive action.

The implementation of the 2030 Agenda depends on combined actions taken by a variety of stakeholders. Collective action of regional and subregional intergovernmental partnerships along with national and sub-national action is needed. National and local level activity is judged to be a key enabler and driver for implementing 2030 Agenda, although the governance levels ultimately is responsible for implementation.

\section{REGIONAL INTEGRATION AND DEVELOPMEN- TAL REGIONALISM}

The most influential report about regional sustainable development has been Reshaping Economic Geography. This World Bank (2009)'s report is firmly grounded in the new economic geography theory, which advocates the advantages associated with the agglomeration effects of large cities: development and growth will be unbalanced and attempts to spread economic activity will not only reduce poverty, they will also undermine growth and prosperity.

The principles developed in this Report inform the debates on how to make globalization works for all countries. The same logic applied at the local and national levels can be used at the international level to classify world regions by the difficulty of economic integration in these regions.

The task of integration varies in different parts of the developing world:

- $\quad$ Regions close to world markets, such as Central America, North Africa, and Eastern Europe, face a relatively straightforward task of integration, and in this case common institutions can help them become extensions of these large markets; 
- $\quad$ Regions distant from world markets, but with large home markets attractive to investors, face a more difficult challenge. Examples include East Asia and, increasingly, South Asia. Southern Africa and South America and these regions can also integrate globally by making their home markets bigger and more specialized through local institutions and infrastructure.

- Integration is hardest for regions that are distant from world markets, and lack the economic density provided by a large local economy mainly in East, Central, and West Africa, Central Asia, and the Pacific Islands. For these regions, instruments are needed, such as regional institutions that thin borders, regional infrastructure that connects countries and such incentives as preferential access to world markets, perhaps conditioned on ensuring that all countries strengthen regional cooperation.

A further Report, Regions Matter by OECD (2009), stresses the individual characteristics of regions and their place specificity and proposes to go beyond "onesize-fits-all" development approaches.

The principle is that no country can tackle the sustainable development challenges alone. Integrated solutions must be found at local, national, regional and global levels. Likewise, businesses and civil society must work towards achieving sustainable development. A local framework for sustainable development is needed to mobilize all stakeholders, explain the challenges, focus operational action at the right scale, and form a basis for a true international partnership.

Most regional economic integration initiatives have the declared intention of pursuing economic development. As we can see in Figure 2, the Association of Southeast Asian Nations (ASEAN), the South Asian Association for Regional Cooperation (SAARC), the Economic Community of the West African States (ECOWAS) were established for the purpose of accelerating economic and social development in their member states.

However, the extent to which many regional integration initiatives actually promote sustainable development is varied, depending upon the ability of the countries involved to manage the adjustment costs that often result from these arrangements. Debates on the merits of regional integration in the promotion of sustainable development are ongoing with opposite results: some scholars consider regional integration as a key element of development with a great potential to support human and economic development, while protectionist measures risk undermining these advantages (Chandra 2009).

\section{Map showing eight regional organisations}

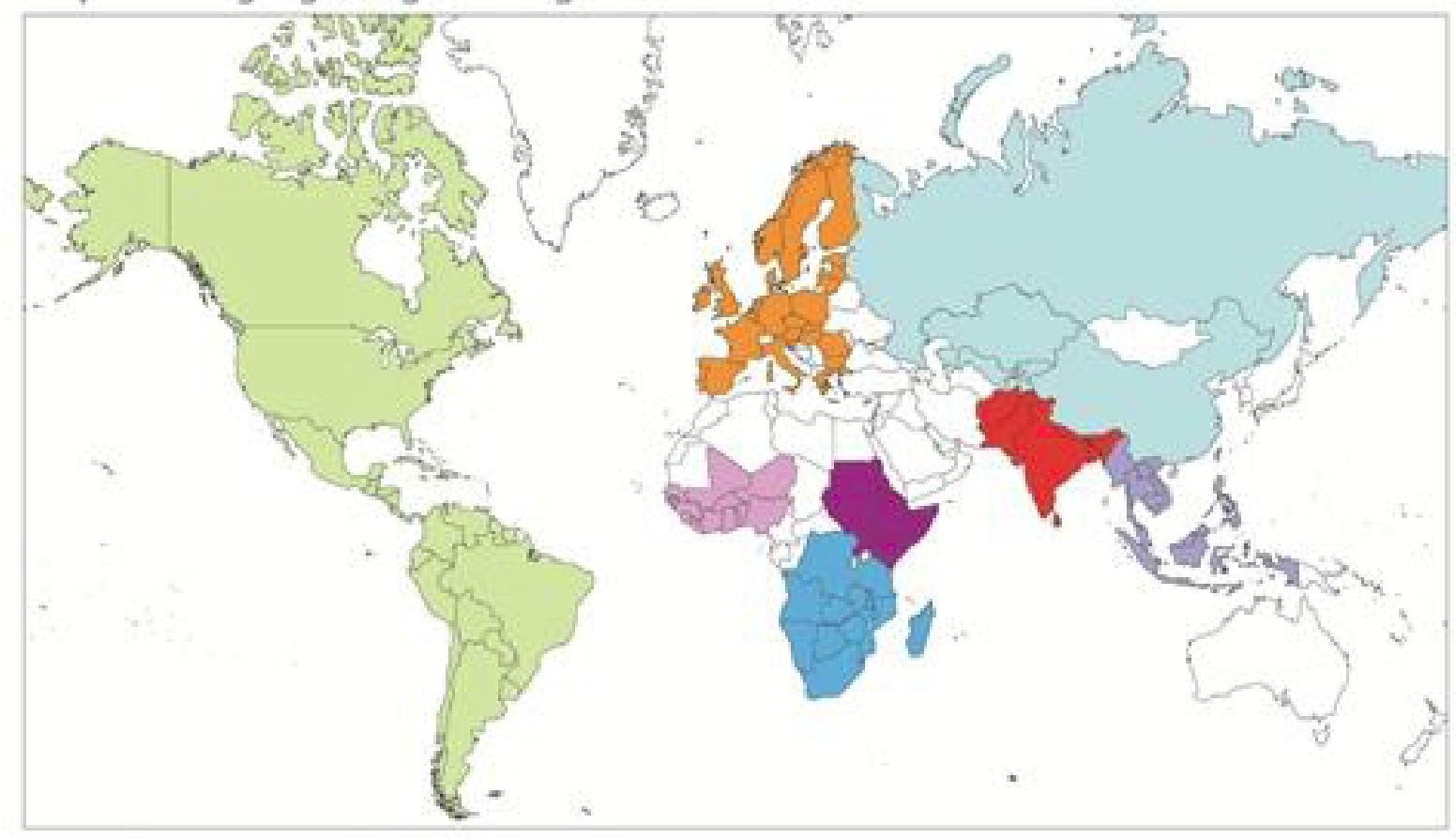

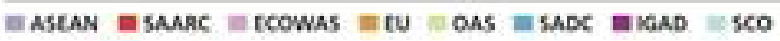

Figure 2: Macro-Regional Economic Areas. 
Despite the attractiveness of using regionalism as a "development" policy, the world shows an uneven development among countries from within the various regions. Apart from that, this focus on trade also led to the exclusion of other equally important parameters of regional integration, such as social and cultural cooperation (Balsiger 2011)

Particularly small economies are in favour of pursuing developmental regionalism, because it not only allows the strengthening of their domestic industries, but its commitment to the world market also provides these countries with the necessary opportunity to expand their market beyond their region when and if necessary. In most cases, regional groupings that favour this form of regionalism impose temporary protection or provide specific privileges for domestic capital in this expanded market. In practice, this approach to regionalism normally involves the participation of firms from outside the region in operating and investing inside the region. However, the economic activities of these foreign firms in the region are also subject to certain restrictions that are not imposed on firms from within the region.

Much attention in the analysis of developmental regionalism has been given to efforts to bridge the development gap among countries within a regional framework, as well as between the region and the rest of the world. However, little attention has been given to the internal development gap that exists within the participating countries of a regional scheme, as well as the ways in which regional organizations could help address such economic disparities in a sustainable development direction.

\section{REGIONAL SUSTAINABLE DEVELOPMENT IN PRACTISE AND THE EUROPEAN MACRO- REGIONS}

A new mode of cooperation of local authorities and non-state actors, as defined by the European Commission (2011), is valued and supported by major international organizations as the expression of a new way of conceiving the equitable and sustainable development among the peoples founded on the actors and relational processes. Compared to the traditional cooperation, the capacity to foster development that is more focused on the priorities of the actors involved is attributed to the cooperation model of territorial partnerships, because of the greater proximity to citizens and local realities.

The pattern of territorial partnerships offers an added value compared to the traditional bilateral form of government, in favour of a participatory approach including some basic principles that should characterize the quality: the recognition of the interdependence and of the need to initiate and sustain a dialogue between political territories (codevelopment); the fairness and reciprocity relations (sharing of responsibilities, commitments, including financial, and rules and compliance) and application of the rules; the support for open and sustainable endogenous development through the enhancement of local vocations and the mobilization of resources and the excellence of the territories involved; the adoption of participatory methods and support of active citizenship, supporting processes of democratization and decentralization that meet the principles of good governance (fairness, accountability, transparency and efficiency).

Sustainable development is the principle that guides the model of territorial partnerships and in fact some experiences of decentralized cooperation make direct reference to the principles and methodology of the Local Agenda 21, that we have analysed above. The European Commission has set out in the Gothenburg Strategy the principle of the interdependence of environmental issues globally, stressing the need to make economic growth, social cohesion and environmental protection go hand in hand in the long run.

This approach has direct effects on internal policies and external assistance policies of the European Union: in the case of decentralized cooperation actors are called upon to adopt the principle of sustainable development in territorial cooperation programs involving neighbouring regions.

The local sustainable development appears particularly appropriate to ensure the processes of coevolution of human society balanced with nature, in respect of future generations. For these reasons, the model of territorial partnerships, as defined above, is a valid mode of action for sustainable development, not only because it must comply with its principles, but also because it is able to test innovative practice that is focused on the process of developing the relationship among civil society, institutions and natural capital of the territories.

There are, therefore, many experiences of territorial cooperation for sustainable development, for example within the framework of European programs for interregional issues, made during institution building 
projects, such as support to the development of rural areas, the growth of small and medium-sized companies with eco-friendly productions and services, biodiversity conservation, fighting desertification, management of key public services, and so on.

The reading of the Local Agenda 21 in terms of working method for the realization of sustainable development processes qualifies such experience to serve as a cultural basis to stimulate local actions that widen the horizon of objectives.

The use of the Local Agenda 21 decentralized development cooperation approach supports and induces the centrality of the issue of environmental sustainability in development within the strategic development of cooperation initiatives. Characteristic to this approach, is the awareness that aspects of economic, social and ecological development must be kept in constant balance and that this is favoured by the constant collaboration between the components of civil society and by their own assumption of responsibility.

The presence of some essential cornerstones of the mechanism, identifiable, as already seen, in the sharing of knowledge and skills in participatory planning, circularity and continuity in the verification of the results and consequent modification of strategies and tools, makes it a good basis for the development of forms of intervention based on the interaction of social and institutional components, starting from the local dimension addressing the issue of sustainability of global development" (Delle Cave 2015).

The application of Local Agenda 21 within the processes of defining strategies and actions for decentralized cooperation represents an opportunity to contribute to the integration of these strategies within the theme of sustainable development and represent needs and stimuli of the civil societies.

In particular in Europe, from the 2009, exist others, internal, regional organizations that we can show in the Figure 3

In this map we distinguish four macro regions: Baltic Sea Region (EUSBSR), born in 2009³ Danube Region (EUSDR), born in 20114; Adriatic and Ionian Region

\footnotetext{
${ }^{3}$ Conclusions of the General Affairs and External Relations Council, 27 October 2009 and Conclusions of the European Council, 29-30 October 2009.

${ }^{4}$ Conclusions of the General Affairs Council, 13 April 2011 and Conclusions of the European Council, 23-24 June 2011.
}

(EUSAIR), born in 2014; ; Alpine Region (EUSALP), born in $2016^{6}$.

These four regions involving $19 \mathrm{EU}$ and 8 non-EU countries, and their objectives are fully in line with EU political priorities: they reinforce synergies between different EU policies and instruments and are anchored in the cohesion policy framework ${ }^{7}$.

The emergence of these macro-regional strategies (MRS) has been driven by a number of EU countries and regions as a complement to traditional country policies on territorial management. They are designed to tackle common challenges using a bottom-up approach involving national, regional and local actors.

The strategies have strengthened cooperation in certain policy areas (for example the Navigability Danube master plan) the extension of the Baltic Energy Market Interconnection Plan (BEMIP), the Strategy on Adaptation to Climate Change in the Baltic Sea Region, or the Core Network Corridors and its links with key cross-border infrastructures. Smart specialization strategies have been used to drive a more effective innovation policy and push interregional cooperation in new value chains across borders.

The dissemination of the macro-regional concept with the support of INTERACT ${ }^{8}$ has led over time to the emergence of a wide array of interests and networks formed by different actors with varying powers and capacities. It has allowed partners to cooperate in specific fields such as research and innovation.

MRS also plays a big role in developing links with non-EU countries, in particular accession countries, strengthening their connection to the EU.

Most of these initiatives and actions need momentum and would benefit from stronger coordination within and between the involved countries to deliver the expected results. The practice of combining the annual forum with ministerial meetings contributes to it, and at the same time raises the

\footnotetext{
${ }^{5}$ Conclusions of the General Affairs Council, 29 September 2014 and Conclusions of the European Council, 23-24 October 2014

${ }^{6}$ Conclusions of Council, 27 November 2015 and the European Council, 28 June 2016.

${ }^{7}$ Regulation (EU) No 1303/2013 of the European Parliament and of the Council of 17 December 2013 laying down common provisions on (the European Structural and Investment Funds) (OJ L 347, 20.12.2013, p. 320); point 31 of Article 2.

${ }^{8}$ INTERACT is an EU-wide programme co-financed by the European Regional Development Fund designated to provide support to the managing authorities of Interreg programmes as well as MRS.
} 


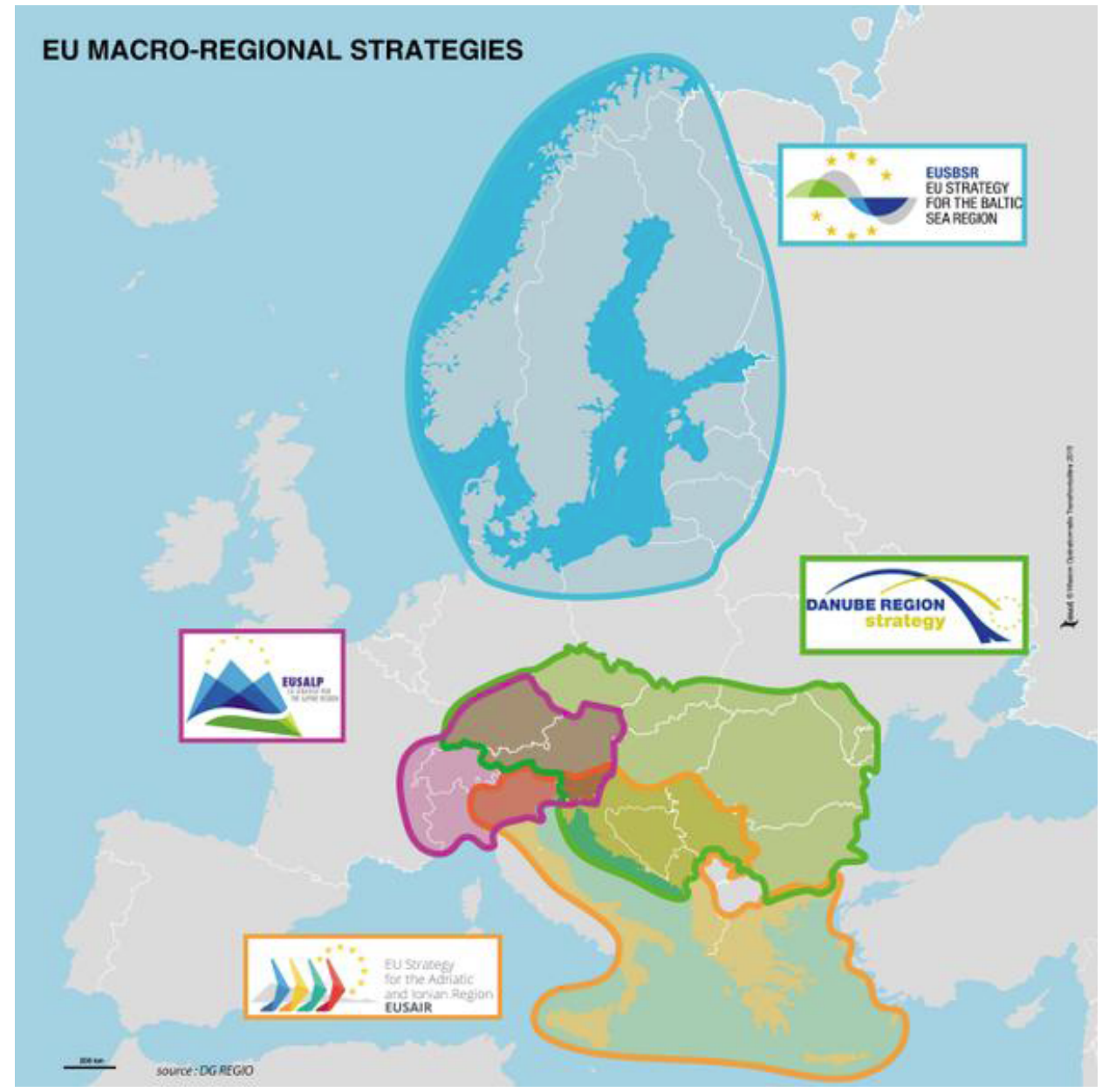

Figure 3: Macro-Regional European Strategic Areas.

political profile of MRS. For example, the experience of the Baltic Sea region shows that long-term strategic thinking must remain the basis for macro-regional cooperation.

\section{CONCLUSION}

The thematic strategy in the IPP Communication by the European Commission's on the Sustainable Use of Natural Resources ${ }^{9}$ focuses on decoupling economic growth from environmental impacts, being a foundation of the indicators to be developed to monitor progress across the community. The global dimension is equally recognized through e.g. the establishment of a supporting International Panel on Natural Resources coordinated by UNEP.

The Commission then provided the Action Plans on Sustainable Consumption and Production (SCP) and on Sustainable Industrial Policy ${ }^{10}$. The plans, that should further help to identify and overcome barriers for SCP, build upon European initiatives and instruments, including the Eco-Management and Audit Scheme (EMAS), the Eco-Label Scheme, the Environmental Technology Action Plan (ETAP), Green Public Purchasing (GPP), the Eco-design of Energy-using Products (EuP) Directive as well as others. The target is to increase coherence among the different related policy areas, while addressing gaps and supporting global interaction.

So while there have been important achievements, there are still barriers that inhibit the broader implementation of sustainability instruments. Drivers for the implementation can be of various nature. They can be legal, based on directives or other requirements set not only by governmental institutions but also by supranational and/or regional bodies (Porrini and Striani 2016). 
To regard the macro-regional strategies we can see that after seven years of implementation are producing their first results, but have not shown their full potential yet. The benefits would be much greater if the Member States who initiated these processes of cooperation would retain greater responsibility. The success of the strategies depends on sound implementation in the years to come, as well as on readiness to adjust to changing circumstances, for example, the migration crisis. There needs to be further progress in the governance of macro-regional strategies.

Also, the MRS have become an important instrument in the relations between EU Member States and their external neighbours, both with accession countries and parts of the Neighbourhood Policy (Eastern Partnership) and the Northern Periphery and the Arctic region ${ }^{11}$. They can foster regional development and cohesion with these countries and nurture the relationships that the EU develops on its external borders.

Reducing regional disparities is as much a goal of MRS as is the creation of synergies for growth and employment in the regions concerned. Macro-regions can help shape an integrated view on the future of the European territory. They can become an important instrument in the pursuit of territorial cohesion across different policy areas, and can also inspire similar approaches as the EU Urban agenda. They call for closer links between EU policy areas and EU funds ${ }^{12}$.

Finally, the benefits of integration for growth and human development will be very good if accompanied by investments in infrastructure, both national and cross border. These investments allow people and inputs to move to more productive opportunities, and allow finished goods and services to reach broader markets (the need is particularly acute in countries with large distances e.g. Africa).

Also, the regional economic integration allows for a new exploration of regional industrial policy. Because of market scale, larger labour pool, and diversified resource and production bases, regional policies that work together with existing comparative advantages

\footnotetext{
${ }^{11}$ European Commission (2016), Report from the Commission to the European Parliament, the Council, the European Economic and Social Committee and the Committee of the Regions on the implementation of EU macro-regional strategies, p. 10.

${ }^{12}$ European Commission (2016), Report from the Commission to the European Parliament, the Council, the European Economic and Social Committee and the Committee of the Regions on the implementation of EU macro-regional strategies, p. 11.
}

stand a greater chance of success. This regional industrial policy could encourage skills upgrading for value added in agriculture and other manufacturing opportunities. The experience of ASEAN countries in support of SMEs and building an integrated economic space by unbundling production across countries provides a valuable reference for the other countries.

To support the process of economic integration many countries need to build strong regional institutions and policies that go beyond the development of regional standards and monitoring. These institutions must also have the instruments and resources necessary to protect the stability of the regional space from internal and external shocks. They must be able to look upward at global challenges and downward to national realities.

In closing, we can note that the enhanced regional integration provides a platform for strengthening cooperation on common environmental challenges and preserving the natural resource base on which countries development and livelihoods depend on.

\section{REFERENCE}

Ascani, A., R. Crescenzi and S. lammarino. 2012. "Regional Economic Development: A Review." SEARCH Working Paper WP1/03

Alkan Olsson, J., T. Hilding-Rydevik, H. Aalbu and Bradley K. 2004. "Indicators for Sustainable Development." European Regional Network on Sustainable Development, Paper for discussion.

Balsinger, J. 2011. "New environmental regionalism and sustainable development." Regional Environmental Governance: Interdisciplinary Perspectives. Theoretical Issues, Comparative Designs (REGov), Procedia Social and Behavioral Sciences 14:44-48.

Barca, F. 2009. "An Agenda for a Reformed Cohesion Policy. A place-based approach to meeting European Union challenges and expectations." Independent Report prepared at the request of the Commissioner for Regional Policy.

Barca, F., P. McCann, and A. Rodriguez-Pose. 2012. "The Case For Regional Development Intervention: Place-Based Versus Place-Neutral Approaches." Journal of Regional Science, 52.1:134-152. https://doi.org/10.1111/j.1467-9787.2011.00756.x

Chandra, A. 2009. "The Pursuit of Sustainable Development through Regional Economic Integration - ASEAN and Its Potential as a Development-orient Organization," Published by the International Institute for Sustainable Development (IISD).

Delle Cave, G. 2015. "The regional partnership model and the sustainable development: the 'Agenda 21' case", www.filodiritto.com.

European Commission. 2011. "Non-State Actors and Local Authorities in Development Actors and activities of the NonState Actors and Local Authorities Thematic Programme."

European Commission. 2016. "Report from the Commission to the European Parliament, the Council, the European Economic and Social Committee and the Committee of the Regions on the implementation of EU macro-regional strategies." 
Harris, Jonathan M. 2003. "Sustainability and Sustainable Development.", International Society for Ecological Economics. February.

OECD. 2009. "Regions Matter."

Porrini, D. and F. Striani. 2017. "Regional development processes and frameworks for sustainable development." pp.15-20 in Life Cycle Approaches to Sustainable Regional Development edited by F. Balkau, G. Sonnemann and S. Massari, Routledge.
UNPD. 2011. "Regional Integration and Human Development: A Pathway for Africa."

World Bank. 2009. "Reshaping Economic Geography."

Zaucha, J. and D. Świątek. 2013. "Place-Based Territorially Sensitive and Integrated Approach." Ministry of Regional Development, Wspólna 2/4. 00-926 Warsaw.

United Nations. 2015. "Transforming our world: the 2030 Agenda for Sustainable Development."

Received on 23-01-2017

Accepted on 09-02-2017

Published on 17-03-2017

DOI: https://doi.org/10.6000/1929-7092.2017.06.07

(C) 2017 Porrini and Striani; Licensee Lifescience Global.

This is an open access article licensed under the terms of the Creative Commons Attribution Non-Commercial License (http://creativecommons.org/licenses/by-nc/3.0/) which permits unrestricted, non-commercial use, distribution and reproduction in any medium, provided the work is properly cited. 